\title{
Certain Normal Characteristics of White Leghorn Females.
}

Horace Atwood

Follow this and additional works at: https://researchrepository.wvu.edu/ wv_agricultural_and_forestry_experiment_station_bulletins

\section{Digital Commons Citation}

Atwood, Horace, "Certain Normal Characteristics of White Leghorn Females." (1928). West Virginia Agricultural and Forestry Experiment Station Bulletins. 220.

https://researchrepository.wvu.edu/wv_agricultural_and_forestry_experiment_station_bulletins/220 @ WVU. It has been accepted for inclusion in West Virginia Agricultural and Forestry Experiment Station Bulletins by an authorized administrator of The Research Repository @ WVU. For more information, please contact ian.harmon@mail.wvu.edu. 
West Virginia University Libraries 


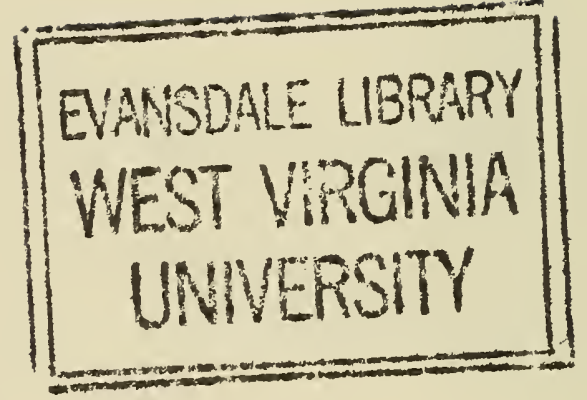


Restricted

Circulation Only

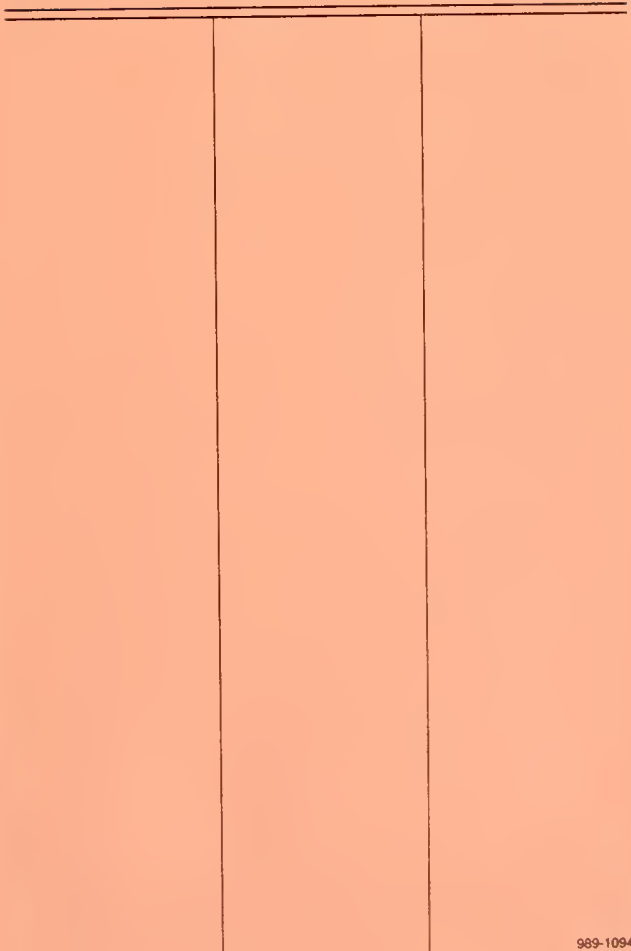





\section{Augricultural Fiprerintent Statimu}

College of Agriculture, West Virginia University

N. J. Giddings, Acting Director

Morgantown

\section{Certain Normal Characteristics of White Leghorn Females}

\section{By}

HORACE ATWOOD 


\section{AGRICULTURAL EXPERIMENT STATION STAFF}

FRANK BUTLER TROTTER, A. M., LL. D.

President of the Univer

N. J. GIDDINGS, Ph. D. Actirg Dean and Dire WALTER C. SCHNOPP, B. S. Agr.

Agricultural Ed JOHN C. JOHNSTON. Chief C

AGRONOMY AND GENETICS

R. J. Garber, Ph. D. Agronomist and Geneticist

E. P. Deatrick, Ph. D. Associate Agronomist (Soils)

T. E. Odland, Ph. D. Associate Agronomist

T. C. MeIlvaine, Ph. D.† Assistant Agronomist (Soils)

D. R. Dodd, M. S.

Assistant Agronomist

M. M. Hoover, M. S.

Junior Agronomist

H. K. Rowley, M. S. Agr.** Seed Analyst

\section{ANIMAL HUSBANDRY}

F. A. Livesay, M. S.

Animal Husbandman

Chas. V. Wilson, M. S.

Assistant Animal Husbandman

J. H. Longwell, M. A.

Assistant Animal Husbandman

J. H. Rietz, D. V. M.

Associate Veterinarian

R. H. Tuckwiller, B. S. Agr.*

Assistant Animal Husbandman

\section{CHEMISTRY}

R. B. Dustman, Ph. D.

Associate Chemist

Chas. E. Weakley, Jr., B. A.

Assistant Chemist

L. P. Hansen, Ph. D.

T. B. Leith, B. A.**

Assistant Chemist

Assistant Chemist

Leland Shriver

Assistant in Chemistry

DAIRY HUSBANDRY

E. L. Anthony, M. S. Agr.

Dairy Husbandman

H. O. Henderson, MI. S. Agr.

Associate Dairy Husbandman

G. Malcolm Trout, M. S.

Assistant Dairy Husbandman

\section{ENTOMOLOGY}

L. M. Peairs, Ph. D.

W. E. Rumsey, B. S.**

Entomologist

State Entomologist

L. E. Dills, M. S.**

Assistant in Entomology

\section{FARM ECONOMICS}

A. J. Dadisman, Ph. D.

Paul A. Ekse, Ph. D.

Assistant F'arm Econor

F. D. Cornell, Jr., M. S.

Junior Farm Mechanic

W. W. Armentrout, M. S.

Junior Farm Econor

\section{HOME ECONOMICS}

Rachel H. Colwell, A. M.

Hazel C. Cameron, M. S.

Home Econor

Research Specialist in Fo

Nell Nesbitt, A. M.

Research Specialist in Home

\section{HORTICULTURE}

IJ. E. Knowlton, Ph. D.

Associate Horticultu

H. L. Crane, M. S. Agr.

Associate Horticultu

K. C. Westover, M. S. Agr.

Assistant Horticultu

Ernest Angelo, M. S. Agr.

Junior Horticultu

L. F. Sutton, B. S. Agr. +

Assistant Horticultu

H. P. Sevy, M. S. Agr. Assistant in Horticult

M. B. Hoffman, M. S. Assistant in Horticult

\section{PLANT PATHOLOGY}

N. J. Giddings, Ph. D.

Anthony Berg, M. S.

Associate Plant Patholog

L. H. Leolian, Ph. D.

Associate Plant Patholog

E. C. Sherwood, M. S.

Assistant Plant Patholog

\section{POULTRY HUSBANDRY}

Horace Atwood, M. S. Agr. Poultry Husbandm

E. T. Wightman, M. S. Agr. Junior Poultry Husbandm

\section{RURAL SOCIOLOGY}

T. L. Harris, Ph. D.

Rural Sociolog

\section{ZOOLOGY}

F. E. Chidester, Ph. D.

Zoolog

*In cooperation with the U. S. Department of Agriculture, Washington, D. C. †In charge of the Lakin Sub-station, Lakin, W. Va.

**In cooperation with the State Department of Agriculture, Charleston, W. Va. fIn charge of the Reymann Memorial Farms, Wardensville, W. Va. 


\section{A Study of Certain Normal Characteristics of White Leghorn Females*}

[PROGRESS REPORT]

In the development and improvement of the different breeds of ultry it is of first importanee to have definite knowledge eoneerning te relationships between the different charaeteristies of the birds, for thout this knowledge no intelligent program ean be adopted. A leeder may need to know how he should proceed to decrease the riation in the size of the eggs laid by his fowls, or to inerease or cerease the average size of the eggs, if that should be desirable. It possible that problems of this nature ean be more quickly and easily aproaehed through a study of the normal relationships of the eharaieristies in the fowls than in any other way.

\section{BIRDS USED AND GENERAL PLAN OF EXPERIMENT}

The strain of Single Comb White Leghorns which was selected this experiment had not been systematieally bred so as to affeet ler the number, the size, or the variability in the size of the eggs ol. In fact, the fowls might well be eonsidered a random sample of mproved White Leghorns.

The general plan of the experiment was to seleet 200 pullets of strain, feed them a laying ration which would be uniform during course of the experiment, and keep a record during the life of the ils of their weight, the number of eggs laid, the weight of each egg, date of laying, and the amount and kind of feed consumed by the ck per month. These data properly analyzed should afford informaon the following points:

1.-The amount of variation in the mean or average weight of the i) rent birds.

2.-The changes in the weight of laying hens from month to month from year to year.

3.--The relationship between body weight and mean egg weight. ther words, the relationship, if any, between the size of the bird the size of the eggs that she lays.

t.- The relationship between the size of the bird and the number igs that she lays.

bmitted for publication March, 1927. 
5.-The relationship, if any, between the size of the eggs and $t$ number which a bird may lay.

6.-The relationship between the variations in the weight of $t$ ? eggs which a bird lays and the number which she lays.

7.-The relationship between early sexual maturity and fecundit

8.- The effect that the age of the bird has on the total annu weight of the eggs that she lays.

9.-The relationship, if any, between the mean decrease in $t$ ] weight of the eggs in the cycles and the annual production.

This experiment was started November 1, 1925, when 200 Sing Comb White Leghorn pullets were placed in small colony laying house The birds were hatched June 15 and had free range until they we: placed in their winter quarters at which time their average weig: was 2.62 pounds. This report covers the first year of the experimer

\section{General Directions}

The following directions were adopted for carrying on th experiment.

\section{GUIDE FOR WEIGHING AND FEEDING}

1.-Weighing Fowls: Fowls to be weighed on the first day of ear month. Weighing to be done early in the morning before the fow are fed and the weight recorded to one-tenth pound.

2.-Weighing Feed: A record is to be kept of the total amount , feed consumed during each calendar month.

3.-Weighing Eggs: Eggs are to be weighed during the forcnoc following the day on which they were laid. Weights to be recorde to one-tenth gram.

4.-Feeding the Fowls: Fowls are to be fed dry mash in hoppes and scratch feed in straw litter. Both the dry mash and the scrate feed are to be thoroughly mixed. The mash is to have the followin composition :

Ingredients

Pounds

Bone Meal 50

Yellow Corn Meal (ground corn). 200

Ground Oats. 100

Wheat Middlings, $161 / 2 \%$ protein. 200

Meat Scrap, 50\% protein. 75

Salt

Powdered Buttermilk. 
The serateh feed is to have the following composition:

\begin{tabular}{|c|c|}
\hline Ingredients & Pounds \\
\hline Yellow Corn & 200 \\
\hline Wh & 100 \\
\hline Clipped Oats... & 100 \\
\hline
\end{tabular}

Germinated Oats are to be fed during December, January, Febru$y$, and Marel at the rate of 2 pounds' dry oats per 100 fowls, per day. i,ster shell and limestone grit are to be given ad libitum.

The scratch feed is to be fed throughout the year at the following tes :

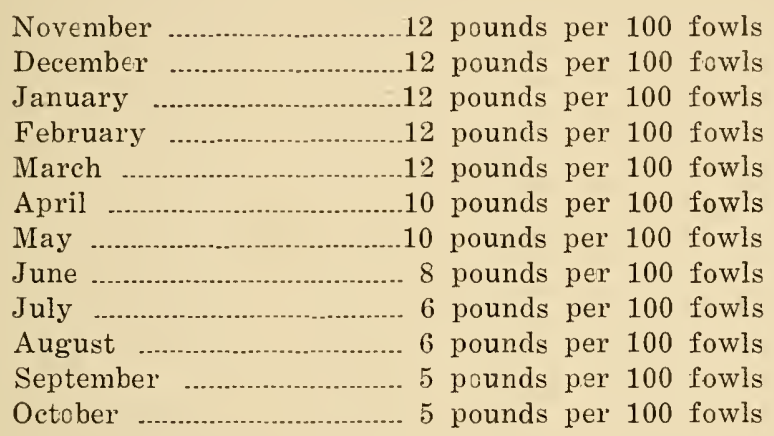

Broody Hens and Moulting: Ail broody hens are to be broken up i promptly as possible, and a record is to be kept of the individuals that lcome broody, length of time broody, the beginning of moult for each idividual, and the length of moult.

\section{Health of the Fowls}

The health of the fowls during the year was good. There were telve mortalities. Six birds were killed by dogs, accidents accounted t: four more, and two deaths were attributed to weakness or disease. te following discussion of the results is based on the records made the 188 birds remaining at the end of the year.

\section{Weight of Birds}

Table 1 gives the mean weight of the 188 birds on the first day of tch month, the standard deviation in their weight, and the coefficient c variability. 
TABLE 1.-Mean Weights of the Pullets Each Month, Standard Deviations Their Weights, and Coefficients of Variability in Weights, Fro November, 1925, to October, 1926.

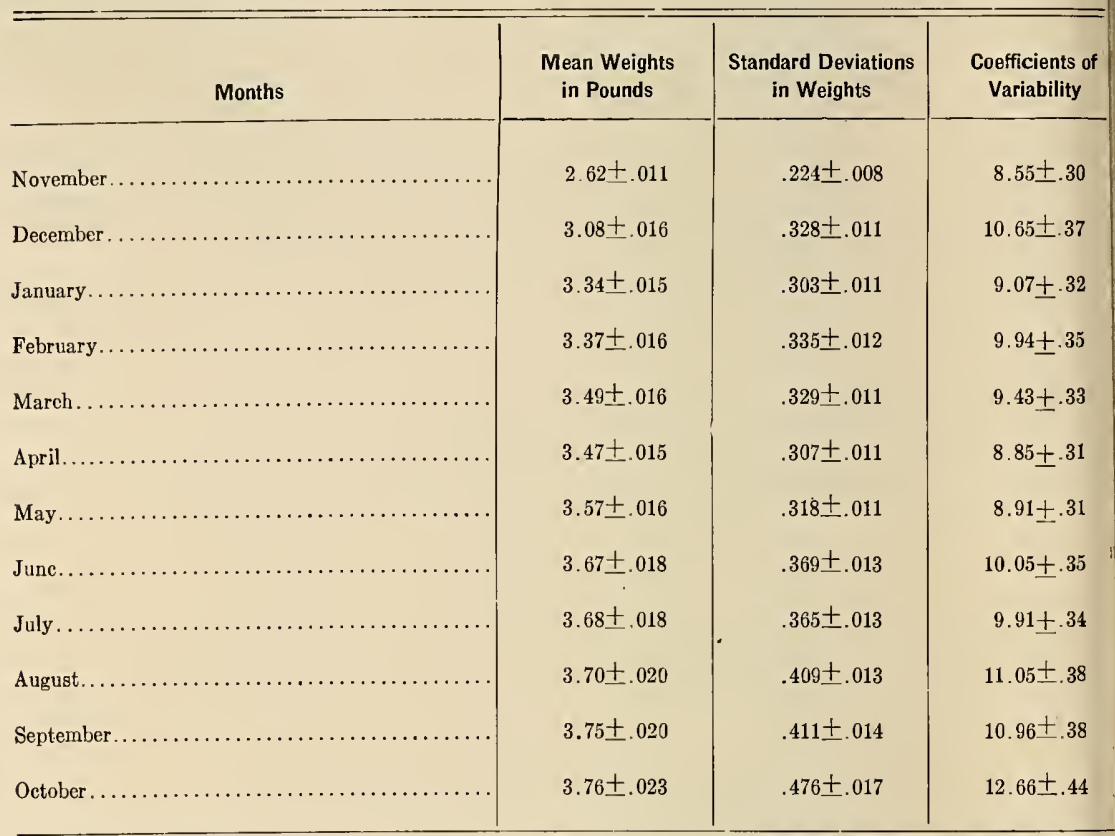

From Table 1 it may be seen that the increase in the weight of tr birds was relatively rapid during November and December. In Jan? ary there was no significant increase; in February there was a sligl gain; in March no significant change; but in April and May there wi some further increase. During the remainder of the year the increas in weight was slight.

The standard deviation in the weight of the different birds in creased considerably during the month of November. From the fir: of December till the first of May there was little change in the devi: tion in weight of the birds, but later in the season the variability $i$ the weight of the birds increased slightly. If it should be shown, $\varepsilon$ now appears probable, that there is a significant positive correlatio between the size of a bird and the mean weight of the eggs that sb lays, then the deviation in the weight of a flock of pullets in the fa could be used as a measure of the variability in the weight of th eggs that they would lay later in the season. Hence, by selectin pullets of a uniform weight the variability in the egg weight woul be kept at a minimum for any particular strain. 
Table 2 gives the average weight of each bird based on the twelve vighings of each individual, and the number and average weight of te eggrs laid by each bird.

DBLE 2.-Average Weights of the 188 Birds That Finished the First Year of the Test, Number of Eggs Laid, and Average Weight of the Eggs Laid by Each Bird.

\begin{tabular}{|c|c|c|c|}
\hline $\begin{array}{l}\text { Band Numbers } \\
\text { of Birds }\end{array}$ & $\begin{array}{l}\text { Average Weights } \\
\text { in Pounds }\end{array}$ & $\begin{array}{l}\text { Number of } \\
\text { Eggs Laid }\end{array}$ & $\begin{array}{l}\text { Average Woights } \\
\text { in Grams }\end{array}$ \\
\hline 2 & 4.37 & 15 & 57.9 \\
\hline 3 & 3.63 & 224 & 55.9 \\
\hline 5 & 3.07 & 153 & 52.5 \\
\hline 6 & 3.46 & 208 & 53.7 \\
\hline 7 & 3.31 & 129 & 46.9 \\
\hline 8 & 3.25 & 142 & 51.2 \\
\hline 9 & 4.21 & 161 & 56.8 \\
\hline 10 & 3.44 & 173 & 54.5 \\
\hline 11 & 3.33 & 182 & 513 \\
\hline 12 & 3.34 & 124 & 49.6. \\
\hline 13 & 3.53 & 127 & $58.2:$ \\
\hline 14 & 3.13 & 193 & 52.4 \\
\hline 15 & 3.73 & 161 & 513 \\
\hline 16 & 3.93 & 163 & 61.8 \\
\hline 17 & 3.41 & 205 & 46.7 \\
\hline 18 & 3.88 & 175 & 55.2 \\
\hline 19 & 3.73 & 150 & 53.8 \\
\hline 20 & 3.11 & 170 & 51.3 \\
\hline 21 & 3.51 & 164 & 47.8 \\
\hline 22 & 3.54 & 156 & 52.0 \\
\hline 23 & 3.21 & 207 & 51.9 \\
\hline 24 & 3.51 & 173 & 53.7 \\
\hline 25 & 3.52 & 200 & 53.8 \\
\hline 26 & 3.87 & 125 & 60.0 \\
\hline 27 & 3.33 & 200 & 50.4 \\
\hline 28 & 3.49 & 193 & 50.3 \\
\hline 29 & 3.60 & 140 & 49.9 \\
\hline 30 & 3.54 & 183 & 50.1 \\
\hline 31 & 3.44 & 176 & 54.2 \\
\hline 32 & 3.52 & 104 & 60.6 \\
\hline 33 & 3.52 & 213 & 52.4 \\
\hline 34 & 3.78 & 155 & 60.1 \\
\hline 35 & 3.50 & 182 & 55.2 \\
\hline 36 & 3.45 & 155 & 57.1 \\
\hline 37 & 3.25 & 140 & 61.9 \\
\hline 38 & 3.64 & 156 & 56.3 \\
\hline 39 & 3.51 & 107 & 54.5 \\
\hline 40 & 3.72 & 209 & 50.5 \\
\hline 41 & 3.53 & 154 & 53.2 \\
\hline 42 & 3.39 & 158 & 50.7 \\
\hline 43 & 3.29 & 118 & 57.2 \\
\hline 44 & 3.77 & 240 & 50.0 \\
\hline 45 & 3.76 & 178 & 52.2 \\
\hline 46 & 3.49 & 161 & 53.5 \\
\hline 48 & 3.37 & 177 & 52.5 \\
\hline 49 & 4.01 & 158 & 54.1 \\
\hline 50 & 3.48 & 153 & 55.3 \\
\hline
\end{tabular}


TABLE 2-Continued.

\begin{tabular}{|c|c|c|c|}
\hline $\begin{array}{l}\text { Band Numbars } \\
\text { of Birds }\end{array}$ & $\begin{array}{l}\text { Average Weights } \\
\text { in Pounds }\end{array}$ & $\begin{array}{l}\text { Number of } \\
\text { Eggs Laid }\end{array}$ & $\begin{array}{l}\text { Average Weights } \\
\text { in Grams }\end{array}$ \\
\hline 51 & 3.31 & 205 & 49.9 \\
\hline 52 & 4.09 & 186 & 59.1 \\
\hline 53 & 3.90 & 211 & 50.8 \\
\hline 54 & 3.48 & 206 & 58.1 \\
\hline 56 & 3.16 & 157 & 54.1 \\
\hline 57 & 383 & 147 & 53.9 \\
\hline 58 & 3.83 & 105 & 56.9 \\
\hline 59 & 3.48 & 148 & 51.3 \\
\hline 60 & 3.32 & 163 & 49.3 \\
\hline 61 & 3.90 & 173 & 56.2 \\
\hline 62 & 3.46 & 195 & 56.8 \\
\hline 63 & 392 & 26 & 59.5 \\
\hline 64 & 3.88 & 194 & 54.4 \\
\hline 65 & 3.47 & 213 & 54.5 \\
\hline 66 & 3.33 & 208 & 48.7 \\
\hline 67 & 3.43 & 227 & 52.4 \\
\hline 68 & $3.3 \mathrm{j}$ & 120 & 56.0 \\
\hline 69 & 3.41 & 176 & 53.3 \\
\hline 70 & 3.70 & 182 & 50.6 \\
\hline 71 & 3.92 & 225 & 56.5 \\
\hline 72 & 3.62 & 56 & 50.2 \\
\hline 73 & 3.58 & 182 & 56.0 \\
\hline 74 & 3.64 & 215 & 54.6 \\
\hline 75 & 3.81 & 224 & 53.3 \\
\hline 76 & 3.54 & 48 & 49.5 \\
\hline 77 & 3.18 & 203 & 49.6 \\
\hline 78 & 2.95 & 36 & 48.0 \\
\hline 79 & 3.76 & 170 & 55.9 \\
\hline 80 & 3.04 & 195 & 51.1 \\
\hline 81 & 3.46 & 149 & 55.3 \\
\hline 82 & 3.47 & 216 & 55.2 \\
\hline 83 & 3.27 & 255 & 50.3 \\
\hline 84 & 3.20 & 227 & 51.2 \\
\hline 85 & 3.63 & 165 & 59.6 \\
\hline 86 & 328 & 123 & 56.0 \\
\hline 87 & 3.37 & 168 & 55.1 \\
\hline 88 & 3.05 & 188 & 53.2 \\
\hline 89 & 348 & 206 & 52.9 \\
\hline 90 & 3.36 & 150 & 53.5 \\
\hline 91 & 3.47 & 167 & 53.5 \\
\hline 92 & 3.21 & 160 & 52.7 \\
\hline 93 & 3.41 & 181 & 54.0 \\
\hline 94 & 3.48 & 190 & 57.5 \\
\hline 96 & 3.89 & 208 & 60.2 \\
\hline 97 & 4.07 & 170 & 51.9 \\
\hline 98 & 3.43 & 184 & 54.7 \\
\hline 100 & 3.30 & 189 & 55.0 \\
\hline 101 & 3.27 & 204 & 52.4 \\
\hline 102 & 3.53 & 54 & 55.2 \\
\hline 103 & 3.46 & 123 & 53.8 \\
\hline 104 & 3.08 & 182 & 49.7 \\
\hline 106 & 3.49 & 173 & 58.4 \\
\hline 107 & 3.39 & 124 & 53.4 \\
\hline 108 & 3.48 & 213 & 50.3 \\
\hline 109 & 3.80 & 233 & 51.7 \\
\hline 110 & 3.60 & 202 & 55.7 \\
\hline
\end{tabular}


BI. 2 -Continued.

\begin{tabular}{|c|c|c|c|}
\hline $\begin{array}{l}\text { Band Numbars } \\
\text { of Birds }\end{array}$ & $\begin{array}{c}\text { Average Weights } \\
\text { in Pounds }\end{array}$ & $\begin{array}{l}\text { Number of } \\
\text { Eggs Laid }\end{array}$ & $\begin{array}{c}\text { Average Weights } \\
\text { in Grams }\end{array}$ \\
\hline 111 & 377 & 113 & 618 \\
\hline 112 & $32 j$ & 2.9 & 49.2 \\
\hline 113 & 3.15 & 181 & 52.9 \\
\hline 114 & 3.00 & 186 & 52.8 \\
\hline 115 & 340 & 196 & 55.2 \\
\hline 116 & 369 & 15.5 & 53.1 \\
\hline 117 & $3.3 j$ & 113 & 49.6 \\
\hline 115 & 3.08 & 172 & 50.0 \\
\hline 119 & 3.53 & 191 & 58.1 \\
\hline 120 & 3.82 & 169 & 54.8 \\
\hline 121 & 3.23 & 166 & 55.0 \\
\hline 122 & 341 & 176 & 54.6 \\
\hline 123 & 378 & 213 & 59.9 \\
\hline 121 & 341 & 199 & 536 \\
\hline $12 ;$ & 297 & 143 & 54.8 \\
\hline 126 & 2.84 & 236 & 47.1 \\
\hline 127 & 3.25 & 221 & 47.7 \\
\hline 123 & 3.83 & 102 & 56.9 \\
\hline 129 & 3.38 & 182 & 516 \\
\hline 130 & 3.40 & 203 & 52.0 \\
\hline 131 & 2.99 & 204 & 51.9 \\
\hline 132 & 2.87 & 207 & 49.9 \\
\hline 133 & 313 & 134 & 51.6 \\
\hline $13 t$ & 3.41 & 201 & 56.0 \\
\hline 135 & 3.60 & 201 & 54.8 \\
\hline 136 & 3.66 & 227 & 53.7 \\
\hline 137 & 3.68 & 140 & 53.5 \\
\hline 138 & 3.16 & 190 & .53 .7 \\
\hline 139 & 3.72 & 99 & 52.9 \\
\hline 110 & 3.25 & 169 & 49.4 \\
\hline 111 & 3.87 & 137 & 54.4 \\
\hline 112 & $3.1 \mathrm{~s}$ & 18 & 510 \\
\hline $1 \pm 3$ & 4.09 & 173 & 53.6 \\
\hline 144 & 3.95 & 178 & 50.1 \\
\hline $14 j$ & $3 . \pi$ & 118 & 57.8 \\
\hline 146 & 3.26 & 195 & 50.5 \\
\hline 117 & 3.59 & 17.5 & 56.6 \\
\hline 145 & 3.14 & 188 & 54.2 \\
\hline $11: 1$ & 3.73 & 163 & 56.6 \\
\hline 1.50 & 3.10 & 212 & 46.3 \\
\hline 1.51 & 3.49 & 179 & 56.8 \\
\hline 152 & 35.5 & 176 & 47.7 \\
\hline 1.54 & 3.16 & 106 & 51.1 \\
\hline $1 . \overline{5}$ & $3.4 j$ & 143 & 54.4 \\
\hline 156 & 3.84 & 189 & $56 . \overline{5}$ \\
\hline $15 i$ & 3.64 & 171 & 52.1 \\
\hline 158 & 3.40 & 143 & 52.6 \\
\hline 159 & 3.78 & 194 & 47.8 \\
\hline 160 & 3.15 & 166 & 48.0 \\
\hline 161 & 3.54 & 140 & 52.3 \\
\hline 162 & 3.27 & 145 & 543 \\
\hline 163 & 3.05 & 157 & 44.9 \\
\hline 164 & 3.73 & 172 & 492 \\
\hline 165 & 3.02 & 150 & 47.6 \\
\hline 166 & 2.97 & 113 & 47.0 \\
\hline 167 & 3.33 & 185 & 529 \\
\hline
\end{tabular}


TABLE 2-Concluded.

\begin{tabular}{|c|c|c|c|}
\hline $\begin{array}{c}\text { Band Numbers } \\
\text { of Birds }\end{array}$ & $\begin{array}{l}\text { Average Weights } \\
\text { in Pounds }\end{array}$ & $\begin{array}{l}\text { Number of } \\
\text { Eggs Laid }\end{array}$ & $\begin{array}{c}\text { Average Weights } \\
\text { In Grams }\end{array}$ \\
\hline 168 & 3.14 & 169 & 53.1 \\
\hline 169 & 2.93 & 140 & 48.6 \\
\hline 170 & 3.60 & 195 & 54.2 \\
\hline 171 & 3.08 & 109 & 50.2 \\
\hline 172 & 3.41 & 141 & 53.0 \\
\hline 173 & 3.43 & 158 & 53.6 \\
\hline 174 & 3.02 & 182 & 51.2 \\
\hline 175 & 3.48 & 228 & 50.1 \\
\hline 176 & 3.93 & 168 & 57.5 \\
\hline 177 & 3.31 & 170 & 53.0 \\
\hline 178 & 3.17 & 181 & 54.7 \\
\hline 179 & 3.56 & 207 & 54.8 \\
\hline 180 & 3.10 & 166 & 50.9 \\
\hline 181 & 3.17 & 216 & 52.8 \\
\hline 182 & 3.60 & 140 & 54.1 \\
\hline 184 & 3.24 & 220 & 54.6 \\
\hline 185 & 3.43 & 110 & 51.8 \\
\hline 186 & 3.47 & 199 & 55.6 \\
\hline 187 & 3.21 & 149 & 45.8 \\
\hline 190 & 3.37 & 126 & 54.3 \\
\hline 191 & 3.20 & 157 & 54.8 \\
\hline 192 & 3.56 & 230 & 49.8 \\
\hline 193 & 3.30 & 125 & 54.5 \\
\hline 194 & 3.10 & 189 & 49.7 \\
\hline 195 & 3.60 & 161 & 53.8 \\
\hline 196 & 3.00 & 180 & 53.0 \\
\hline 197 & 3.38 & 230 & 52.9 \\
\hline 198 & 3.42 & 183 & 55.5 \\
\hline 200 & 3.28 & 143 & 57.6 \\
\hline
\end{tabular}

The mean weight of the birds, based on the average weight each individual, was $3.46 \pm .013$ pounds; the standard deviation of $t$ average weights of the birds was $.274 \pm .010$; and the coefficient variability was $7.92 \pm .27$. These figures probably represent with fair degree of accuracy the variability in weight of an unselected str: of White Leghorn pullets.

The total number of eggs laid by the 188 birds was 31,682 . For five birds laid 200 or more eggs each, while only eight birds laid fev than 100 eggs each. The production ranged from a maximum of : eggs in the case of bird 83 to a minimum of 15 for bird 2 . The av age egg weight varied from a maximum of 61.9 grams for bird 37 a minimum of 44.9 grams for bird 163 . The average weight of all 1 eggs laid during the year by the 188 birds, including the eggs ( 4.6 ? laid outside the trap nests, was 53.09 grams.

Due to the immaturity of the pullets the production during winter months was low as shown in Table 3 , but with the beginning spring the production materially increased, reaching a maximum May with an average daily production of 144.13 eggs from 188 bir 
size of the eggs should this be desirable to meet market requiremes 'To throw some light on this condition, the coefficient of correlation been calculated, using the average body weight and average weight of the 188 birds under discussion. The coefficient thus deri is $+.459 \pm .039$. This is clearly significant as the coefficient is alm twelve times the probable error. These results agree with those sho by the author in Bulletin 195, and the conclusion seems justified $t$ the heavier birds in a flock lay the heavier eggs.

The relationship between the number of eggs that a bird will dependent on whether they are large or small is also important $t$ producer.

The coefficient of correlation between the number of eggs' laid the different birds and the average weight of the eggs laid by the se birds is $-.136 \pm .048$. As this coefficient is less than three times probable error, the evidence indicates that there is no relation betw the number of eggs laid by a bird and the average size of the es This result, too, is in agreement with the earlier findings of the aut reported in bulletins 182 and 195 of this Station.

In breeding to increase the egg production of a flock, it is equ as important to decrease the number of very poor layers as it is increase the production of the better layers, hence it is of value have data on an unselected strain showing what may be designe as the normal variability in respect to the number of eggs laid by various females. The standard deviation in the number of eggs has been calculated and has been found to be $41.52 \pm 1.44$. This high deviation and shows that there was a very material variabi in the number of eggs laid by the birds in the flock.

As to whether the heavier birds of this flock laid as many $e$ as their smaller companions, the coefficient of correlation betwcen weight of the birds and the number of eggs laid has been found th $-.159 \pm .047$. This coefficient is not significant, as it is only al three times its probable error, and consequently as far as these go the smaller birds of this flock laid equally as well as the larger 0

The pullets that develop fastest during the summer and lay in the fall should have a better opportunity to make a good egg ree during the first laying year than their companions that begin to later in the season. It is possible, nevertheless, that the birds that velop more slowly will lay more steadily after they begin to lay hence make as good or better records than those that begin to earlier in the season. In order to study this matter the coefficien 
in hand, at least during the pullet year. This relationship is also sho clearly by Figures 1 and 2 . Figure 3 shows the mean egg product: for each month of the year.

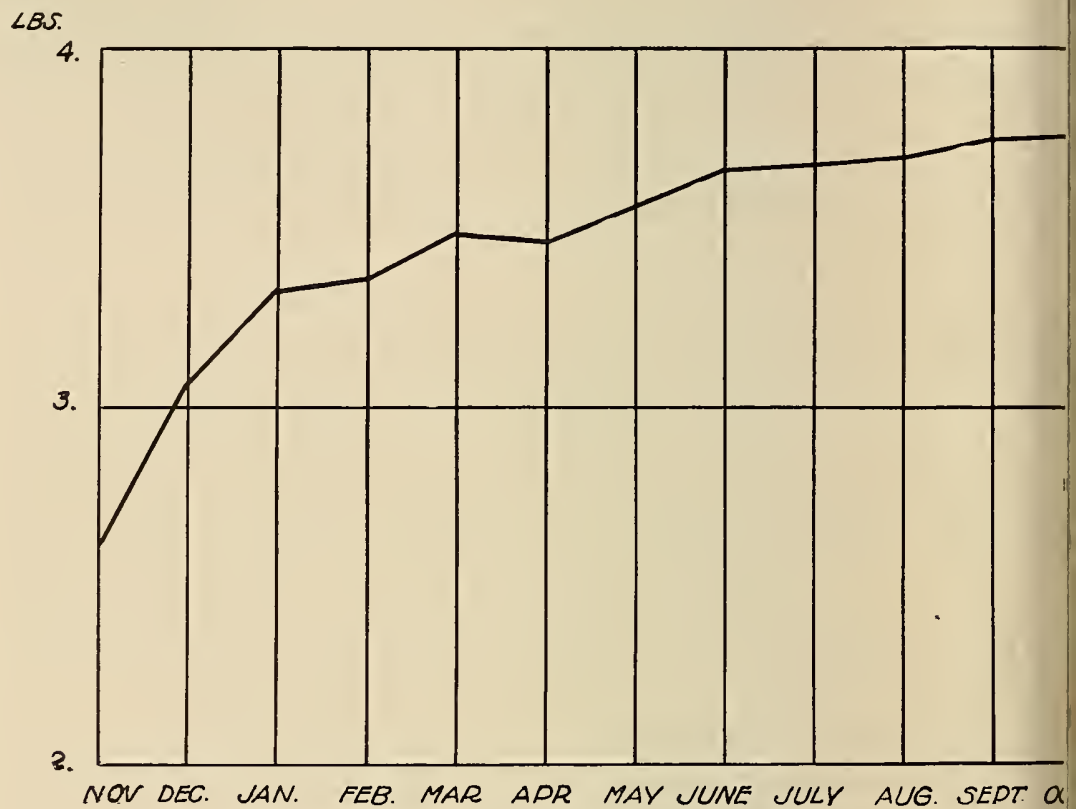

Fig. 1-Mean monthly weights of birds.

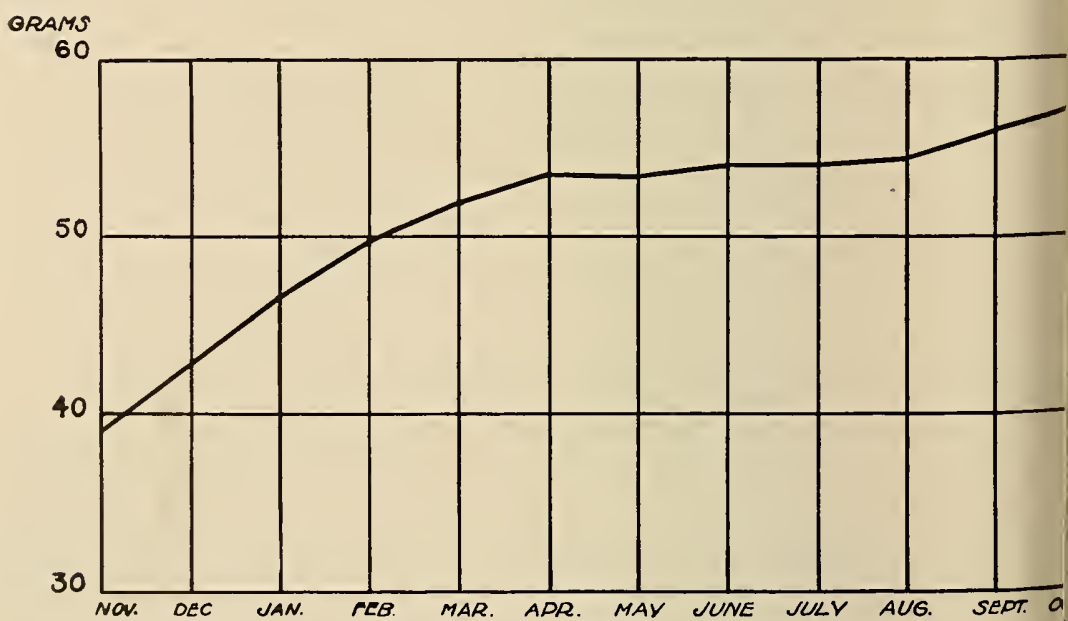

Fig. 2-Mean monthly weights of eggs. 


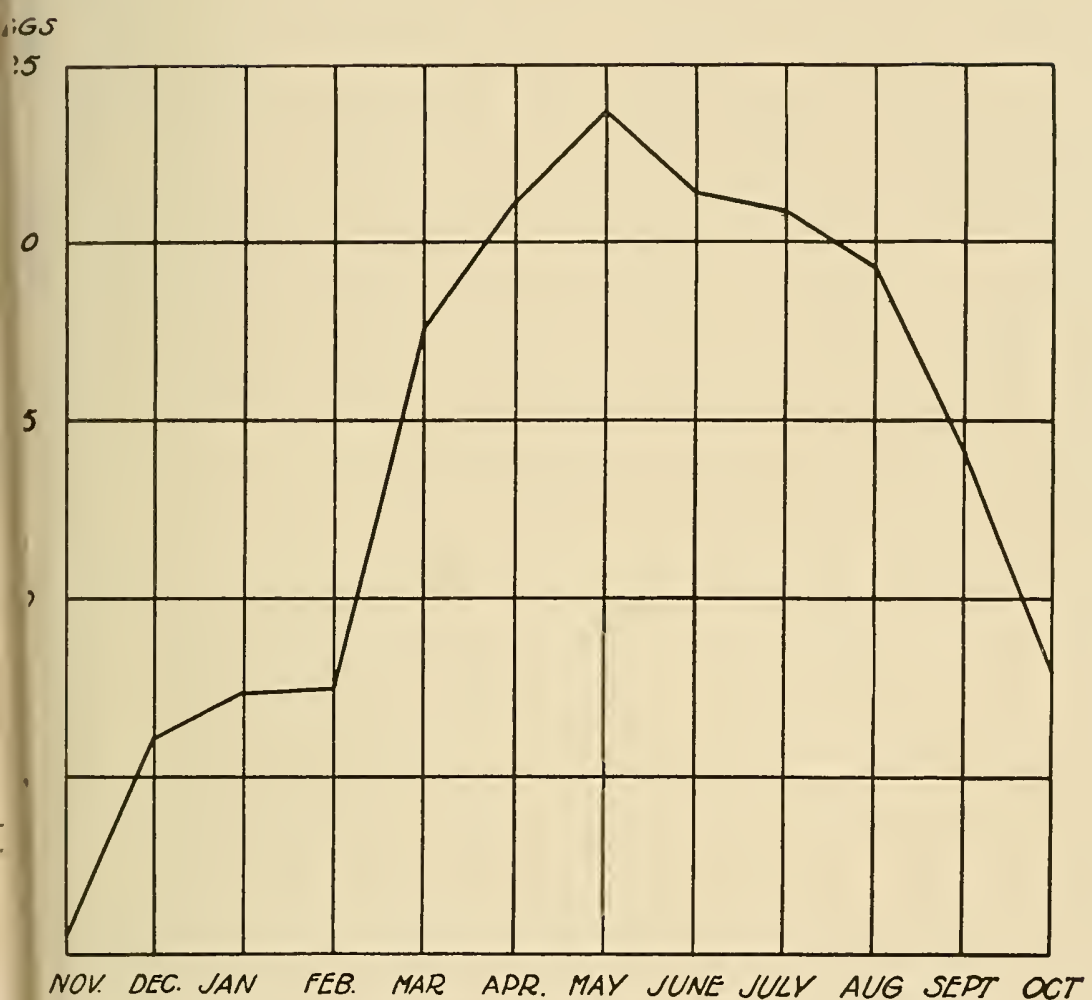

Fig. 3-Mean egg production per month. 


\section{SUIMMARY}

In this bulletin is discussed the record of 188 Single Comb Wh Leghorn pullets during their first laying year, or from October 1925, to November 1, 1926.

During the year all of the eggs that were laid were weighed in vidually and the weight recorded to one-tenth gram. Each bird w also weighed monthly.

1.- The average weight of the different birds ranged from a mi: mum of 2.84 pounds to a maximum of 4.37 pounds. The mean weig of the birds at the beginning of the year was 2.62 and at its clc 3.76 pounds.

2.-The egg production ranged from a minimum of 15 eggs to maximum of 255 . The average production for the year was 168 . eggs. Eight birds laid fewer than 100 eggs each, while forty-five le 200 or more.

3.-The average weight of the eggs laid by the different bir ranged from a minimum of 44.9 grams to a maximum of 61.9 grar The mean weight of all eggs laid during the year was 53.09 grams.

4.-Based on the eggs laid in the trap nests, forty-seven bir each laid during the year a total weight of ten thousand grams more or eggs.

5.-With but slight exceptions, the average size of the eggs creased from the beginning of the year to its close.

6. - The heavier birds laid the heavier eggs.

7.- There was no relation between the number of eggs laid by bird and the size of the eggs.

8.-There was no relation between the size of the bird and $t$ number of eggs that she laid.

9.-The birds that were youngest when beginning to lay li more eggs during the first year than did their companions th matured more slowly.

10.-There was no relation between the average size of a $b$ : and her age when reaching sexual maturity.

11.-The increase in the weight of the birds and the increase the mean weight of the eggs were closely related throughout the ye 


HECKMAN
BINDERY INC. JUNE 99 Bound-To-Please N. MANCHESTER
INDIANA 46962 
(1)

(1)

(5)

(4)

int 4

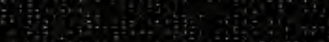

(1)

- 40

Sho

(6)

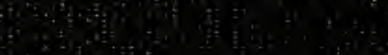

1.2.

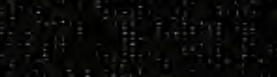

1.

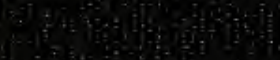

2.

a

(n)

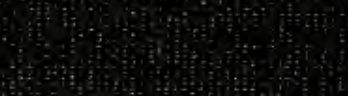

10

${ }^{4}+{ }^{2}$

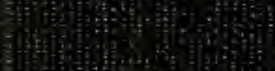

(1) 